\title{
STUDIES ON THE DIENCEPHALON OF THE CAT
}

I. THE CYTO-ARCHITECTURE OF THE CORPUS GENICULATUM LATERALE

B. D. THUMA

Department of Anatomy, Uniwersity of Michigan

ONE HELIOTYPE PLATE AND NINETEEN TEXT FIGURES

\section{INTRODUCTION}

While engaged in a study of the thalamus of the cat, which study is to form a link in a series of investigations on the comparative anatomy of the diencephalon of vertebrates which this department is projecting, the writer became absorbed in a study of the cellular configuration of the lateral geniculate body, in point of size and complexity-the most interesting thalamic nucleus in this animal. The literature is replete with experimental studies on the projection of the retina on the corpus geniculatum laterale and of this nuclear mass on the visual cortex. Good reviews are to be found in the papers of Minkowski ('13), Kappers ('21), and Henschen ('26). A recent account of the cortical relations of the optic projection fibers is given by Poljak ('27). But although the use of the cat has been extensive in this work, studies of the normal anatomy of the lateral geniculate body in this animal are few.

Outside of the work of Cajal ('11), the only papers which treat of this nucleus in the cat with any degree of detail are those of Tello ('04) and Minkowski ('13). Tello first demonstrated that the lóbulo dorsal and lóbulo redondo of Cajal were in reality parts of one continuous nucleus which, as a result of a peculiar folding, gives the impression of two distinct nuclear groups when sectioned transversely. $\mathrm{He}$ 
describes the lateral geniculate body in the cat as consisting of a large ' $S$ '-shaped cell mass of more or less homogeneous structure, traversed by three medullary laminae, and of a small ventral or accessory nucleus. However, Tello was more interested in Golgi studies of the nucleus than in its cyto-architecture and, as a consequence, made no attempt to describe in detail, section by section, cell distribution and internal configuration. Furthermore, his diagrams are few and highly schematic and leave much to be desired.

Other authors, with the possible exception of Minkowski, in their brief descriptions of the normal lateral geniculate body in the cat, pay scant attention to the internal configuration of the nucleus; and Minkowski only refers to the cellular laminations in any detail when certain of them appear to be significant in atrophic changes subsequent to enucleation of the eye or destruction of the visual cortex. In general, he confirms Tello's account, although he describes a 'griseum reticulatum perigeniculatum,' and his drawings and photomicrographs give a somewhat more adequate picture than those of Tello. However, Minkowski makes no attempt to follow section by section the development and relation of the cellular laminae throughout the longitudinal extent of the nucleus, since he concentrated his attention, as did most of the other workers, on degenerative changes and used, in the main, methods calculated to emphasize these changes rather than the normal eell grouping. Consequently, his deseription of the nuclear mass is incomplete.

Thus a rather more extended investigation of the normal structure of the lateral geniculate body in the cat seems desirable, not only from the point of view of pure anatomy, but also in view of the rather conflicting results which recent experimental investigations have presented. As Henschen notes in a recent paper ('26), our knowledge of the normal histology and cytology of the corpus geniculatum laterale is at present very imperfect; consequently, a comparative study of the cyto-architecture and fiber relations of the nucleus in the higher mammals, at least, should aid materially in the 
solution of the problem of localization around which such a controversy has been waged between the respective schools of Henschen ('26) and v. Monakow ('14). As a contribution toward this end the writer submits the following study.

\section{MATERIAL AND METHOD}

The following description is based upon a complete series of transverse sections of the brain of a normal cat of about one year of age. The material was sectioned at $50 \mu$ intervals and stained with toluidin blue after the method described elsewhere (Huber, '27). To Dr. G. Carl Huber, who prepared this series, I wish to express my indebtedness and sincere appreciation not only for the loan of this material and for kindly placing at my disposal the facilities of the laboratory of anatomy, but also for his interest and his many helpful suggestions and criticisms. My special thanks are due to Dr. Elizabeth Crosby for her innumerable helpful suggestions, and her careful checking of the work.

The optic fibers which pass through and arise within the lateral geniculate body of the cat give rise to such a complicated system of intranuclear differentiation as to make it difficult, from description alone, to visualize the structure in three dimensions, even after repeated examination of the complete series of sections. In order, then, to facilitate somewhat the task of description, a model (fig. 2, A) of 25 diameters' magnification was built up of layers of cardboard after the manner of the usual wax reconstructions. The model was put up in five detachable sections (fig. 2, B), the boundaries of which were located approximately at points of maximum rate of change in each of the typical internal patterns which the dorsal nucleus presents in cross-section. This type of construction permits of an examination of the way in which a particular type of internal pattern develops from the previous type. While these divisions of the model are no doubt arbitrary and in themselves of no particular functional significance, they do serve as landmarks which are helpful in making the model represent something approaching an 
adequate picture of the internal structure of the dorsal nucleus, at the same time obviating the necessity of building the model in an inconvenient number of separable sections.

In addition to the model, a series of drawings (figs. 3 to 14) has been prepared of transverse sections taken at appropriate intervals. The outlines of the nuclear masses were traced by means of the Leitz-Edinger projection apparatus at a magnification of 30 diameters. The cells were depicted in a semischematic fashion with the view of giving a general idea of the relative cell size and distribution as the sections appear under low power. In connection with each of these figures, the number of the series, the slide and the section from which it was drawn, are given. The arrows on the drawings indicate the plane of the schematic longitudinal reconstruction shown in figure 15 . In this figure the level of each transverse section is specified. The drawings of the individual cells were made with the oil-immersion lens and camera lucida.

The question of terminology has presented some difficulties as a result of the rather diverse usages of the different authors. However, in so far as possible, the nomenclature of Winkler and Potter ('14) has been adopted, as it assumes the least in the way of functional significances and homologies; and the other terms which have been added we have tried to make consistent with those borrowed. Some terms have been taken from Minkowski with such slight modifications as we have deemed appropriate. In the description the terms used by Winkler and Potter, and Minkowski have been placed in parenthesis after the term adopted by us.

It is not necessary here to go into detail regarding the relations of the lateral geniculate body to the gross structures of the brain stem. However, for the purpose of general orientation the reader is referred to figure 1 , which represents the dorsal surface of the brain stem of the cat with the cerebral and cerebellar hemispheres removed. The position of the lateral geniculate body has been indicated schematically by the cross-hatched areas. The dorsoventral relations of 
the nucleus with regard to the surface of the thalamus and its position relative to the other thalamic nuclei are depicted in figures 9 and 14, which are complete sections of the dien-

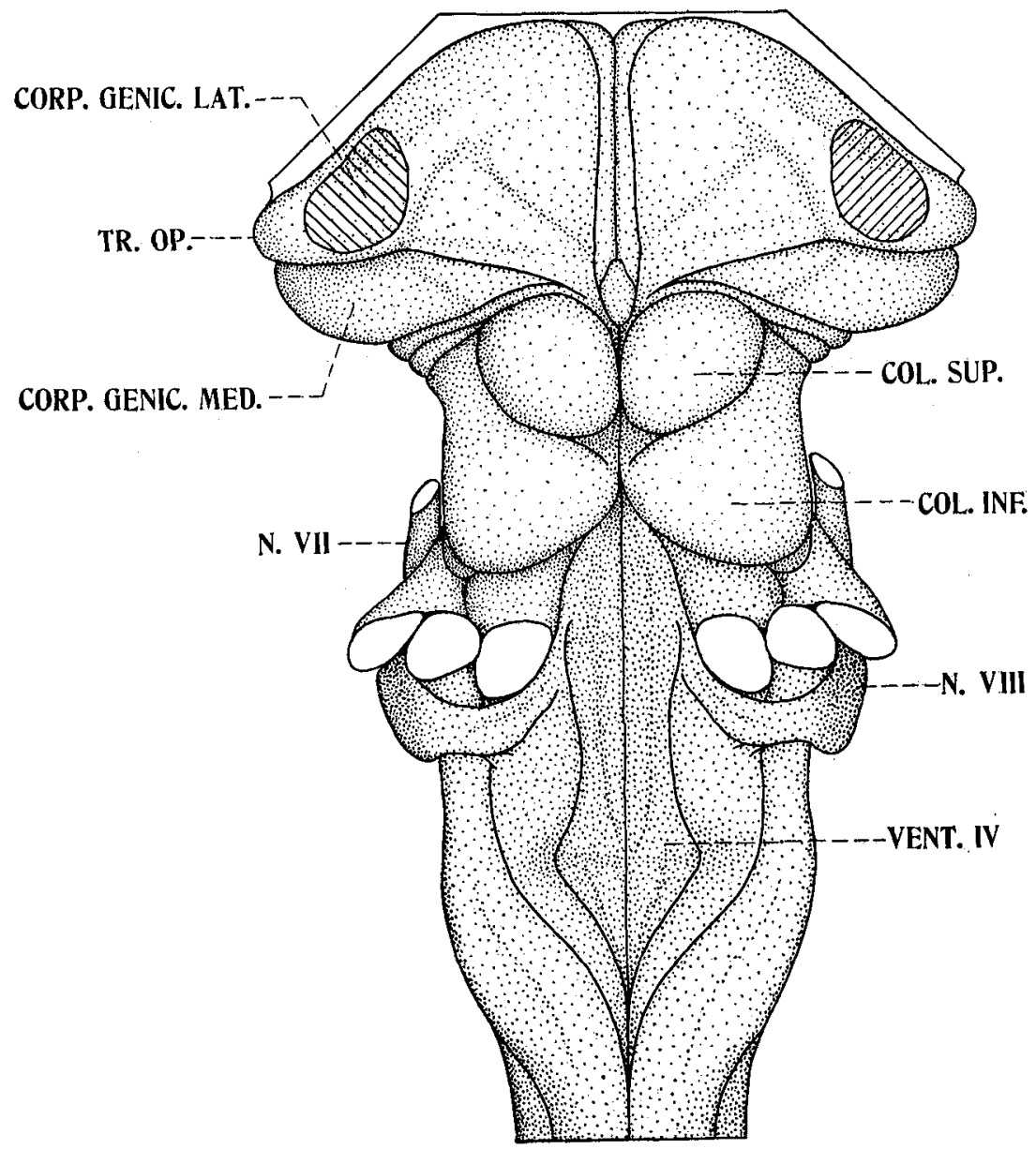

Fig. 1 View of the dorsal surface of the brain stem of the adult eat with the cerebellum and the cerebral hemispheres removed, showing the location of the corpus geniculatum laterale in relation to the gross features of the dieneephalon and midbrain. col.inf., collieulus inferior; col.sup., collieulus superior; corp.genic.lat., corpus genieulatum laterale; corp.genie.med., corpus genieulatum mediale; N.VII, nervus facialis; N.VIII, nervus acusticus; tr.op., tractus opticus; vent.IV, ventriculus quartus. 
cephalon, A brief reference to these figures will be sufficient to orient the reader, and we shall now pass to the description of the serial sections.

\section{CORPUS GENICULATUM LATERALE}

Pars dorsalis; nucleus interlaminaris centralis; nucleus interlaminaris medialis. The dorsal part (pars dorsalis A) of the lateral geniculate body makes its appearance in the midst of the scattered pale cells of the nucleus perigeniculatus (griseum reticulatum perigeniculatum, Minkowski ('19)), cephalad of the caudal extremity of the nucleus semilunaris thalami, between the latter and the nucleus lateralis ventralis thalami. The nuclear mass originates as a disc of large, medium-sized, and small deeply staining multipolar cells. This disc of cells is so located in the section that a horizontal plane passing through its center intersects the walls of the third ventricle slightly ventral to the anterior extremity of the medial habenular nucleus which, at this level, consists of a small mass of cells immediately beneath the stria medullaris.

The large cells (fig. 20, A, B, C) were found to measure $30 \mu$ to $40 \mu$ in diameter and correspond to the large cells of Tello and Minkowski ('13). The latter reports cells as large as $65 \mu$, but we have never been able to find any such. The medium-sized cells (fig. 20, G) measure $20 \mu$ to $25 \mu$ in diameter and appear to stain less deeply than the larger variety. The small cells range between $10 \mu$ to $20 \mu$ in diameter. The concurrence of these three types of cells seems to be characteristic of the pars dorsalis $A$ and $A_{i}$ and, in general, the number of each seems to be inversely proportional to their size.

Some $0.25 \mathrm{~mm}$. $(250 \mu)$ caudad to its point of origin the central portion of the disc of cells becomes less dense and the disc develops into a ring (fig. 3), the center of which contains only a few scattered cells mainly of the larger size. The ring rapidly enlarges and there soon appears within it a small concentric dise of similar cell structure (pars dorsalis 
$A_{1}$ ). Separating the outer ring from the inner dise is a layer of fiber bundles in which are scattered cells of the larger type. On the whole, so far as cell relations are concerned, the fiber lamina appears to have replaced the mediumsized and small cells, the larger cells having retained the same density in this region.

From this point backward the growth of the component parts of the structure is unequal. The lateral wall of the enclosing ring thickens considerably, while the medial wall becomes attenuated. At the same time, the inner disc takes a

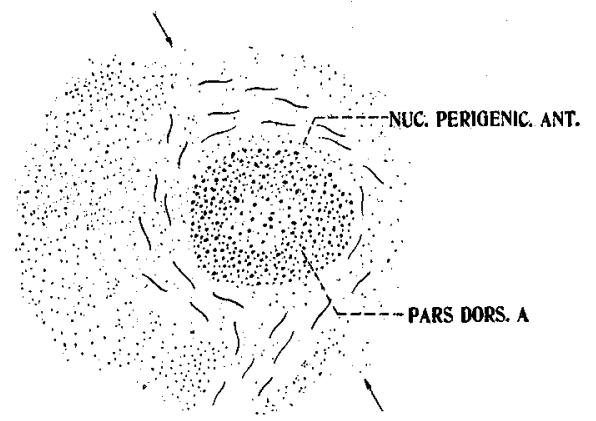

Fig. 3 Transverse section through the anterior part of the lateral geniculate nucleus of the cat. $\times 8$. Toluidin-blue series, no. $1: 174: 1$. Level indicated in figure 15. (See also p. 176.) nuc.perigenic.ant, nueleus perigeniculatus anterior; pars dors.A, pars dorsalis $\mathrm{A}$.

shape much resembling the heel of a shoe, the concave edge of which is directed medially. The sharp dorsal and ventral tips of this concave portion push into the thin medial wall of the enclosing ring capturing between them a small bit of the wall. The structure at this point thus presents the appearance depicted in figure 4. In this figure the semicircular investing layer, pars dorsalis A, is designated by Minkowski as the 'äussere periphere Schicht.'

As the series progresses caudalward, the inner heel-shaped plate (pars dorsalis $A_{1}$ ) continues to enlarge and spread apart the ends of the broken medial wall, the ventral end of which seems to fuse with the ventral surface of the inner 
plate (fig. 5). The central part of the inner plate has, by this time, thinned out considerably and the plate soon splits along its horizontal diameter. The dorsal and ventral halves thus
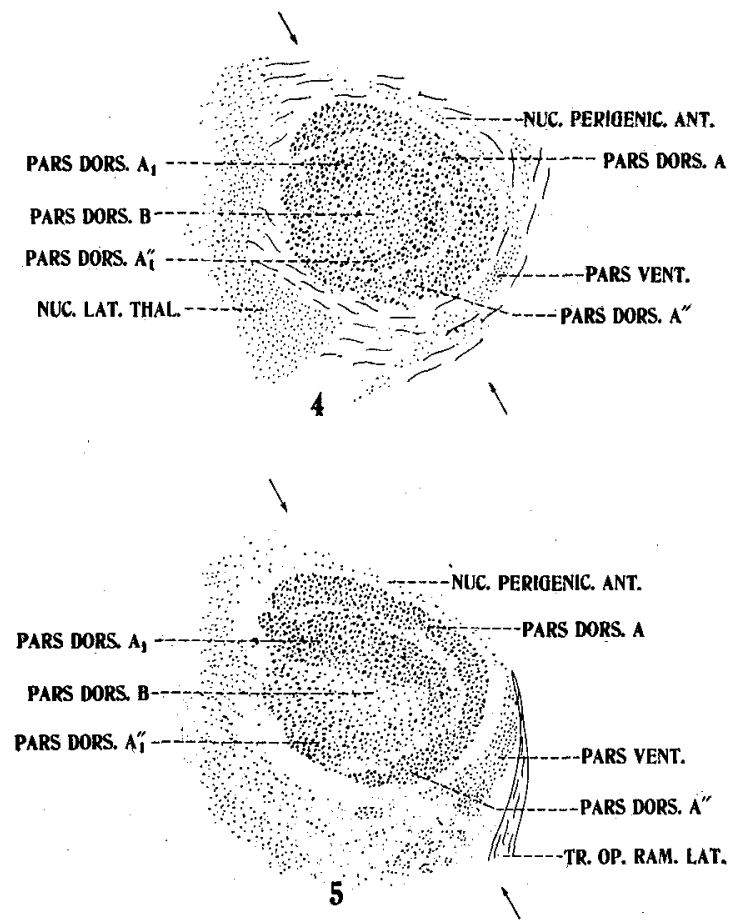

Fig. 4 Transverse section through the anterior part of the lateral geniculate nucleus: of the adult cat. $\times 8$. Toluidin-blue series, no. 1:169:1. Level indicated in figure 15. nuc.lat.thal., nucleus lateralis thalami; nuc.perigenic.ant., nucleus perigeniculatus anterior; parsdors. $A, A^{\prime \prime}, A_{1}, A_{1}^{\prime \prime}, B$, pars dorsalis $\mathrm{A}$, $\mathrm{A}^{\prime \prime}, \mathrm{A}_{1}, \mathbf{A}_{1} ", \mathrm{~B}$; pars vent., pars ventralis.

Fig. 5. Transverse section marking the boundary of the anterior third of the lateral geniculate nucleus of the cat. $\times 8$. Toluidin-blue series, no. 1: 166:1. Level indicated in figure 15. nuc.perigenic.ant., nucleus perigeniculatus anterior; parsdors.A, $A^{\prime \prime}, A_{1}, A_{1} ", B$, pars dorsalis $\mathrm{A}, \mathrm{A} ", \mathrm{~A}_{1}, \mathrm{~A}_{1} ", \mathrm{~B} ;$ parsvent., pars ventralis; trop.ram.lat., tractus opticus ramus lateralis.

formed separate and within the intervening space there are scattered a few of the smaller type of cell (pars dorsalis B). The number of cells in the outer medullary lamina has decreased, but so far as cells are present they are predominantly of the larger size. 
The dorsal portion of the ruptured plate, pars dorsalis $\mathbf{A}_{1}$ (zentrale Schicht of Minkowski), retains its identity as a distinct cell group throughout almost the entire remainder of the nucleus. The ventral portion, however, of what was previously the heel-shaped dise (pars dorsalis $A_{i}$ ) becomes the ventral arm of the outer crescentic cell group, thus marking the fusion ventrally of these two parts of the pars dorsalis. The rather large, deeply staining cells of this ventral arm gradually decrease in number, giving way to the multiplica-

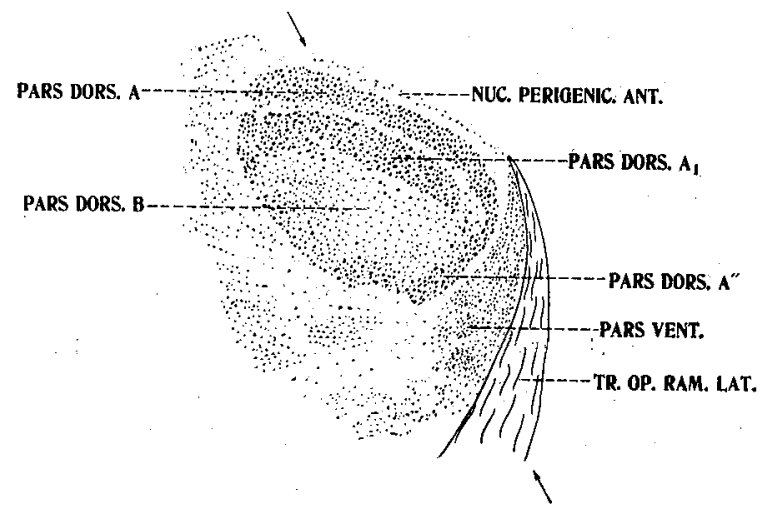

Fig. 6 Transverse section through the anterior part of the middle third of the lateral geniculate nucleus of the cat. $\times 8$. Toluidin-blue series, no. 1: 162:1. Level indicated in figure 15. nuc.perigenic.ant., nucleus perigeniculatus anterior; pars dors. $A, A^{\prime \prime}, A_{1}, B$, pars dorsalis A, A", $\mathrm{A}_{1}, \mathrm{~B}$; pars vent., pars ventralis; tr.op.ram.lat., tractus opticus ramus lateralis.

tion of the smaller, more faintly staining cells mentioned above. These latter, smaller cells now form the pars dorsalis B (nucleus dorsalis B of Winkler and Potter, and, as far as can be judged from Minkowski's photographs, the 'innere periphere Schicht' of that author). The cells of the pars dorsalis $B$ are rather spindle-shaped, about $20 \mu$ to $25 \mu$ long and $10 \mu$ wide. Their appearance and size suggest that they are essentially the same as the medium-sized cells of the pars dorsalis $A$ and $A_{1}$, although elongated as a result of their intercalation within a fiber path. Figure 6 represents the configuration of the nucleus at this level. 
Thus far the pars dorsalis $A$ and $A_{1}$ have retained the same relative position in the section which they had at the outset. However, from now on their geometric center moves dorsally with respect to the floor of the third ventricle and the habenular nucleus.

At approximately the midpoint in the longitudinal extent of the nuclear mass, the medial fibers of the optic tract (tractus opticus ramus lateralis) begin to penetrate the ventrolateral surface of the nucleus, which surface is now composed almost entirely of the small spindle-shaped cells. As will be seen from figure 7 , this smaller-celled area comprises about half the cross-sectional area of the nuclear mass at this level despite the fact that Minkowski describes it as "einen schmalen, an den Tractus Opticus angrenzenden Streifen" (Minkowski, '13, p. 285), and Tello fails to mention it at all.

Just below the lateral geniculate body the optic tract divides, the medial branch, tractus opticus ramus medialis (cinta óptica profunda of Tello), entering the nucleus and the lateral branch, tractus opticus ramus lateralis (cinta optica externa of Tello), passing up the lateral wall of the nucleus and sweeping across the dorsal surface into the region of pulvinar. Figure 7 represents the outlines of the lateral geniculate body at this level. For some distance caudally the same general aspect is maintained.

In figure 7, pars dorsalis $\mathrm{A}^{\prime}$, of a cell structure similar to pars dorsalis $\mathbf{A}$ and $\mathrm{A}_{1}$, makes its appearance at the extreme dorsal surface of the thalamus immediately under the lateral tip of the transverse fissure. This small group of cells represents a bit of the dorsal portion of the pars dorsalis A which has been split off from the main cell mass by the large band of optic fibers sweeping into the region of pulvinar. It is the cell group originally designated as the lóbulo dorsal by Cajal and as the pars dorsalis by Minkowski.

As the series proceeds caudally this small dorsal cell group enlarges ventrally in inverse proportion to the number of optic fibers bound in the direction of pulvinar and becomes 
divided into a pars dorsalis $A_{1}^{\prime}$ dorsally and a pars dorsalis $A^{\prime}$ ventrally. These parts are thus termed simply because they are really continuations of the pars dorsalis $A_{1}$ and $A$, respectively, as may be seen from a study of figure 15 . The downward development of pars dorsalis $\mathrm{A}^{\prime}$ is soon followed by an upward growth of an arm from the dorsolateral portion of pars dorsalis $\mathrm{A}$ in such a manner that, in a few following

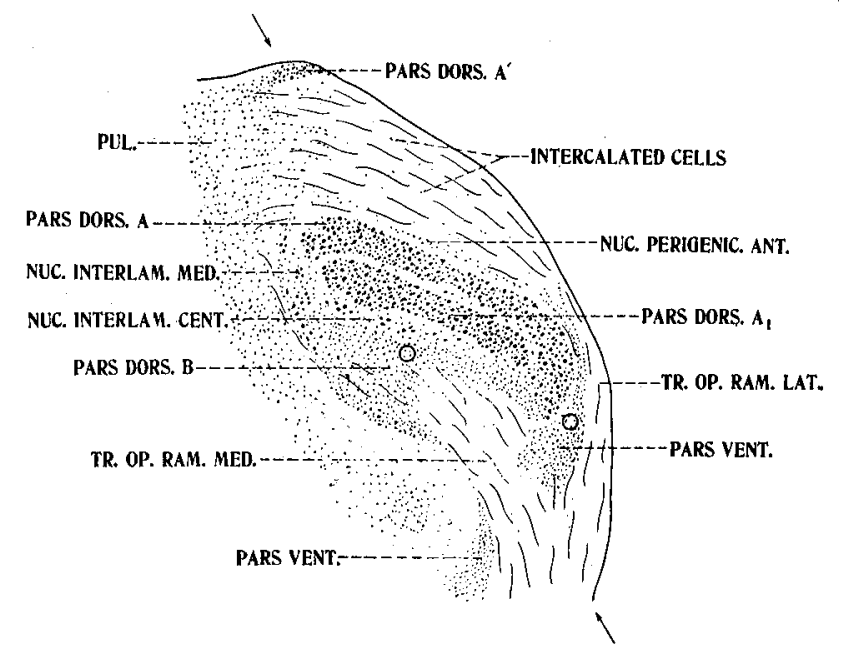

Fig. 7 Transverse section through the middle of the lateral geniculate nucleus of the cat. $\times 8$. Toluidin-blue series, no. $1: 158: 2$. Level indicated in figure 15 . The eircles mark the regions from which figures 17 and 18 were drawn. nuc.interlam.cent., nucleus interlaminaris centralis; nuc.interlam.med., nucleus interlaminaris medialis; nuc.perigenic.ant., nueleus perigeniculatus anterior; pars dors. $A, A^{\prime}, A_{1}, B$, pars dorsalis $\mathrm{A}, \mathrm{A}^{*}, \mathrm{~A}_{1}, \mathrm{~B}$; pars vent, pars ventralis; pul., pulvinar; trop.ram.med., tractus opticus ramus medialis; tr.op.ram.lat., tractus optieus ramus lateralis.

sections, the two groups fuse along the dorsolateral wall of the thalamus to enclose a lagoon of white substance which opens toward the pulvinar. This lagoon represents the hilus in cross-section and, according to the recent study of Putman ('26), the fibers streaming through it are bound for the visual cortex, the area striata, and form the optic radiation.

Meanwhile, the medial portion of the optic tract (tractus opticus ramus medialis) which swings into pars dorsalis B 
has increased into a broad band which nearly obliterates this portion. The pars dorsalis $B$ has now become more nearly Minkowski's 'schmalen . . . . Streifen' along the optic tract.

Throughout this central region of the nucleus the large cells continue to scatter themselves through the medullary laminae. For want of a better name, we have designated these large cells in the fiber laminae as the nucleus interlaminaris centralis. Whether they deserve to be honored

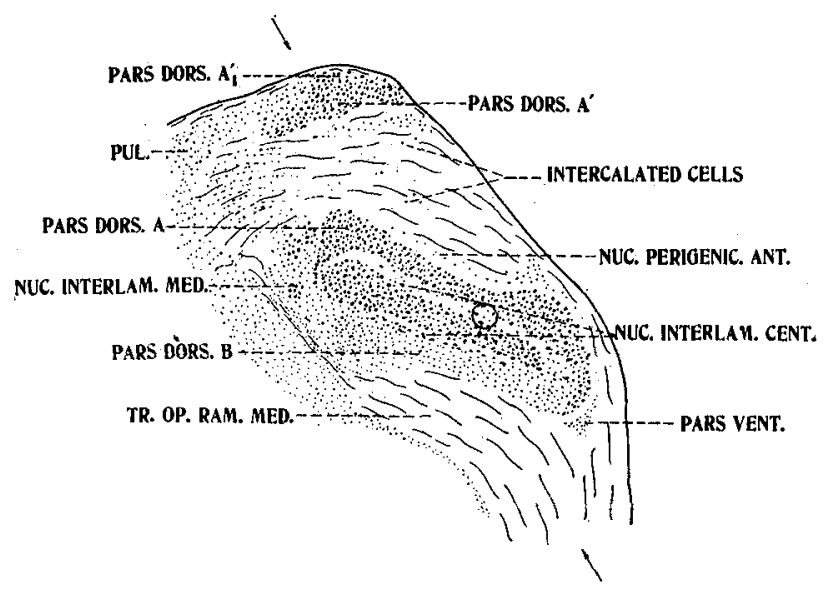

Fig. 8 Transverse section through the central portion of the lateral geniculate nucleus of the eat. $\times 8$. Toluidin-blue series, no. 1: 154:1. Level indieated in figure 15. The circle marks the region from which figure 16 was drawn. nuc.interlam.cent., nucleus interlaminaris centralis; nuc.interlam.med., nucleus interlaminaris medialis; nuc.perigenic.ant., nucleus perigeniculatus anterior; pars dors. $A, A^{\prime}, A_{1}^{\prime}, B$, pars dorsalis $\mathbf{A}, \mathrm{A}^{\prime}, \mathrm{A}_{1}^{\prime}, \mathbf{B}$; pars vent., pars ventralis; pul., pulvinar; tr.op.ram.mer.. tractus opticus ramus medialis.

with the term nucleus is a question, but we regard the structure as sufficiently unique to require a name.

On reference to the figures (figs. 7 to 12) depicting the middle region of the nucleus in the cephalocaudal direction, one will also note clusters of large cells just medial to the main mass of the dorsal nucleus. These are of a structure similar to the pars dorsalis and appear to be broken off from it. Their composition is indicated in figure 19, which was drawn under high power with camera lucida. These clusters 
we have designated as the nucleus interlaminaris medialis; again the terminology is admittedly only tentative. Although some of the large cells appear sporadically along the ventral edge of the tractus opticus ramus medialis, in our material we are unable to find as a distinct nuclear differentiation the

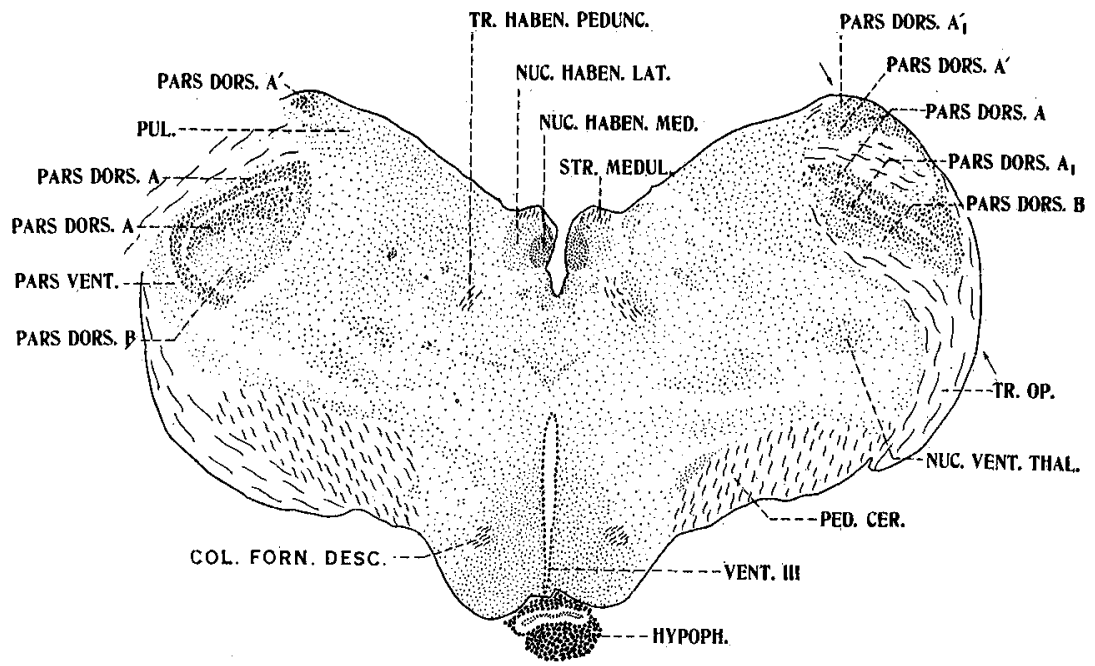

Fig. 9 Transverse section of the thalamus of the cat through the region of the habenular nuclei and the middle third of the lateral geniculate nuclei. The section cuts the left nueleus more anteriorly than the right. Note the relatively large area occupied by the lateral geniculate nuclei. $\times 4$. Toluidin-blue series, no. 1: 151:2. col.forn.desc., columna fornicis descendens; hypoph., hypophysis; nuc.haben.lat., nucleus habenularis lateralis; nuc.haben.med., nucleus habenularis medialis; nuc.vent.thal., nucleus ventralis thalami; parsdors. $A, A^{\prime}, A_{1}, A_{1}{ }^{\prime}, B$, pars dorsalis $\mathrm{A}, \mathrm{A}^{\prime}, \mathrm{A}_{1}, \mathrm{~A}_{1}^{\prime}, \mathrm{B}$; pars vent., pars ventralis; ped.cer., peduneulus cerebri; pul., pulvinar; str.medul., stria medullaris; tr.haben.pedunc., tractus habenulopeduncularis; tr.op., tractus opticus; vent.III, ventriculus tertius.

"thin row of large cells on the inferior and lateral surface of the nucleus' to which Putman refers ('26).

Returning to the serial description of the sections, we find that at the caudal border of the hilus the pars dorsalis $\mathrm{A}$ splits vertically, leaving a canal, canalis hilomedullaris, communicating between the central medullary lamina and the hilus. Passing caudally, the pars dorsalis $A^{\prime}$ fuses on the 

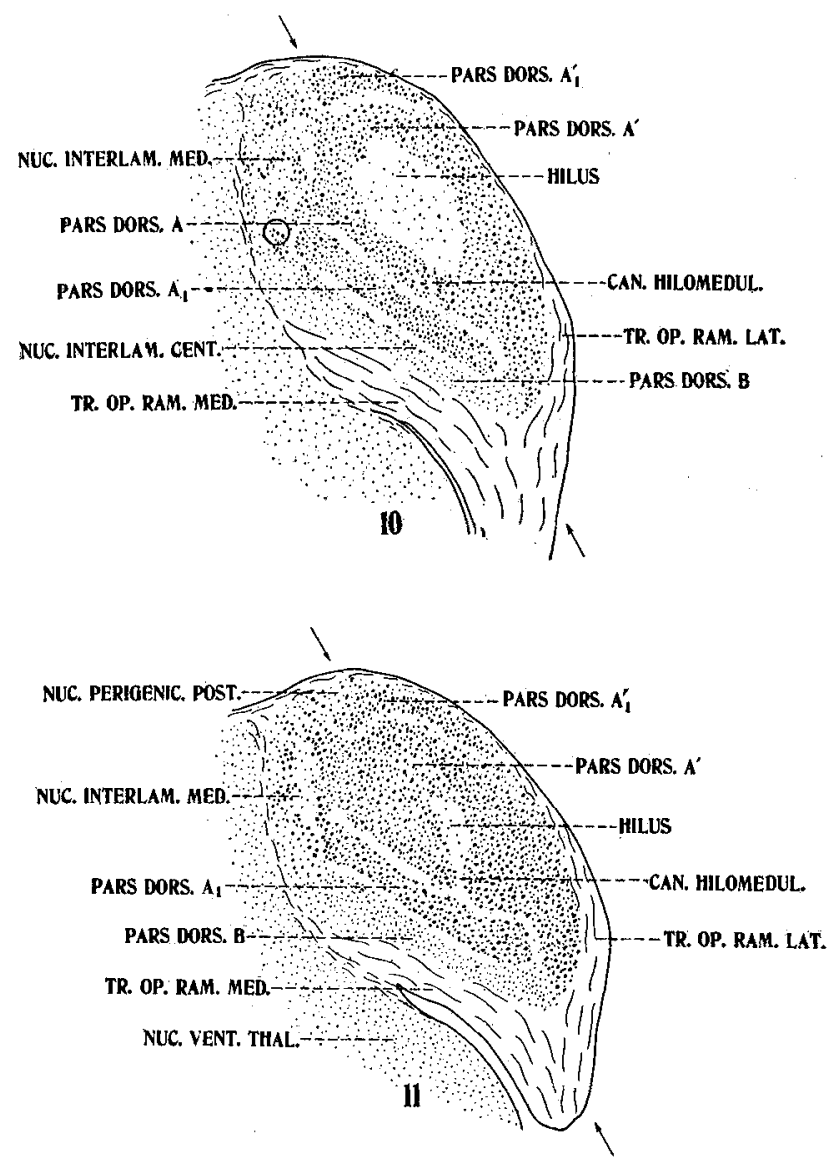

Fig. 10 Transverse section through the posterior part of the middle third of the lateral genieulate nucleus of the eat. $\times 8$. Toluidin-blue series, no. 1: 150:1. Level indieated in figure 15. The circle marks the region from which figure 19 was drawn. can.hilomedul., canalis hilomedullaris; nuc.interlam.cent., nucleus interlaminaris centralis; nuc.interlam.med., nucleus interlaminaris medialis; pars dors. $A, A^{\prime}, A_{1}, A_{1}^{\prime}, B$, pars dorsalis $\mathrm{A}, \mathrm{A}^{\prime}, \mathrm{A}_{\mathrm{x}}, \mathrm{A}_{1}^{\prime}, \mathrm{B}$; tr.opram.lat., traetus opticus ramus lateralis; tr.op.ram.med., tractus opticus ramus medialis.

Fig. 11 Transverse section through the anterior part of the posterior third of the lateral geniculate nucleus of the cat. $\times 8$. Toluidin-blue series, no. 1:148:2. Level indicated in figure 15. can.hilomedul., canalus hilomedullaris; nuc.interlam.med., nucleus interlaminaris medialis; nuc.perigenic.post., nucleus perigeniculatus posterior; nuc.vent.thal., nucleus ventralis thalami; pars dors.A', $A_{1}, A_{1}{ }^{\prime}, B$, pars dorsalis $\mathrm{A}^{\prime}, \mathrm{A}_{1}, \mathrm{~A}_{1}{ }^{\prime}, \mathrm{B}$; tr.op.ram.med., tractus opticus ramus medialis; tr.op.ram.lat., tractus optieus ramus lateralis. 
medial side with the medial extremity of the pars dorsalis A, which is now the ventral wall of the hilus. This presents the configuration shown in figure 10.

From now on the internal pattern changes rapidly and finally resolves itself into the small dise of cells which marks the caudal termination of the nuclear mass. In this process of resolution the lateral wall of the hilus splits down the

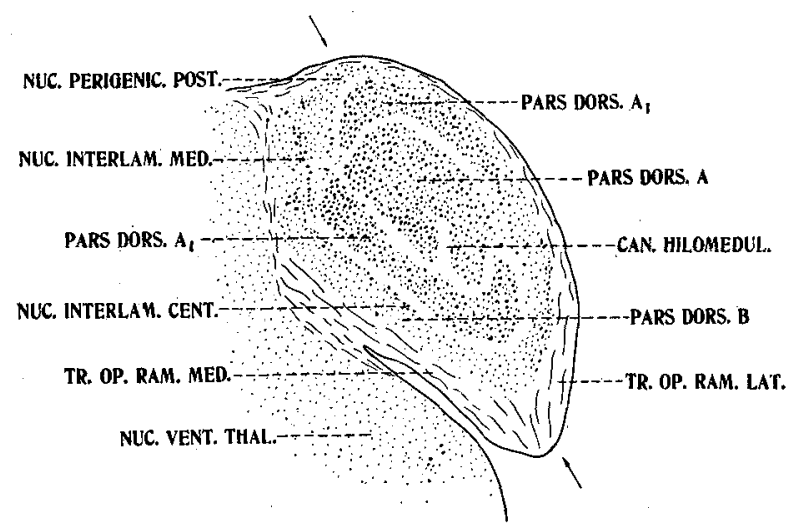

Fig. 12 Transverse section through the middle of the posterior third of the lateral geniculate nucleus of the cat. $\times 8$. Toluidin-blue series, no. $1: 146 ; 2$. Level indicated in figure 15. can.hilomedul., canalis hilomedullaris; nuc.interlam.cent., nucleus interlaminaris centralis; nuc.interlam.med., nucleus interlaminaris medialis; nuc.perigenic.post., nucleus perigeniculatus posterior; nuc.vent.thal., nucleus ventralis thalami; pars dors.A, $\boldsymbol{A}_{1}, B$, pars dorsalis $\mathrm{A}, \mathrm{A}_{1}, \mathrm{~B}$; tr.op.ram.lat., tractus opticus ramus lateralis; tr.op.ram.med., tractus opticus ramus medialis. (Pars dorsalis $A_{1}$, as labeled in the figure, is on the border-line between pars dorsalis $A_{1}$ and pars dorsalis $\mathbf{A}_{1}^{\prime}$, see fig. 15.)

middle in a direction parallel to its lateral surface, leaving a narrow lateral band of cells and a central ring-like structure which surrounds the hilus. The lateral band fuses dorsally with the pars dorsalis $A^{\prime}{ }_{1}$ and ventrally with the pars dorsalis $A_{1}$, as shown in figure 12. This fusion thus provides an outer crescentic lamina which envelops-dorsally, laterally, and ventrally - a central disc of cells with an indentation in its ventral surface which represents all that remains of the hilus. 
Simultaneously with these maneuverings of the large-celled masses, the pars dorsalis B spreads up around the largecelled portion on both sides, so that in figure 12 the dorsal large-celled group is entirely surrounded by a layer of smaller cells which, for want of a better name, we have designated as the nucleus perigeniculatus posterior.

The diameter of the entire structure then rapidly diminishes. The large cells are the first to disappear, leaving a disc of small pale cells which is in turn lost in an envelope of fibers. The fiber capsule forms a small eminence or knob

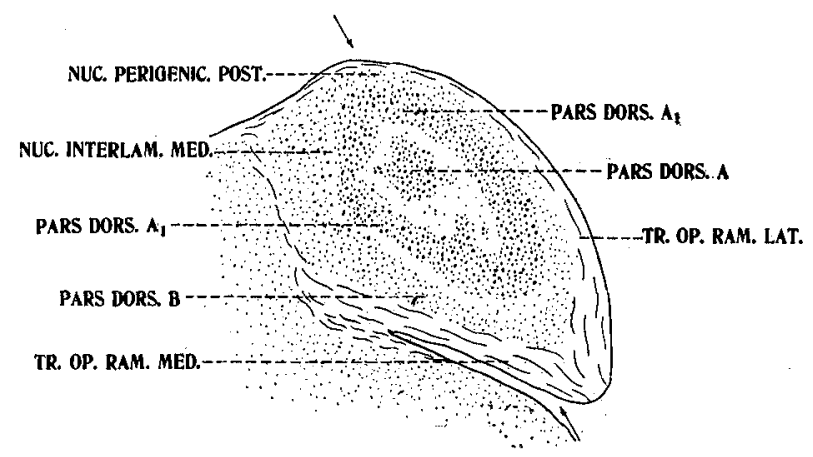

Fig. 13 Transverse section through the middle portion of the posterior third of the lateral geniculate nucleus of the cat. $\times 8$. Toluidin-blue series, no. 1: $145: 1$. Level indicated in figure 15. nuc.interlam.med., nucleus interlaminaris medialis; nuc.perigenic.post., nucleus perigeniculatus posterior; pars dors. $A, \boldsymbol{A}_{1}$, $B$, pars dorsalis $\mathrm{A}, \mathrm{A}_{1}, \mathrm{~B}$; tr.op.ram lat., tractus optiens ramus lateralis; tr.op. ram.med., tractus opticus ramus medialis.

on the dorsolateral surface of the diencephalon. In these sections it disappears entirely at the level which passes through the caudal portion of the posterior commissure.

Nucleus perigeniculatus anterior. This nucleus, which, so far as our interpretation permits, corresponds to the griseum reticulatum perigenieulatum of Minkowski, has its origin about $0.2 \mathrm{~mm}$. cephalad to the section in which the first large cells of the pars dorsalis make their appearance. In our material the nucleus consists of small, very pale cells the details of which are difficult to make out, owing to their light color and the thickness of the sections. 
The pars dorsalis A appears in the center of this dise of cells, and as the former rapidly increases in size the small pale cells of the nucleus perigeniculatus anterior are forced apart, so that in the first few sections of the pars dorsalis A

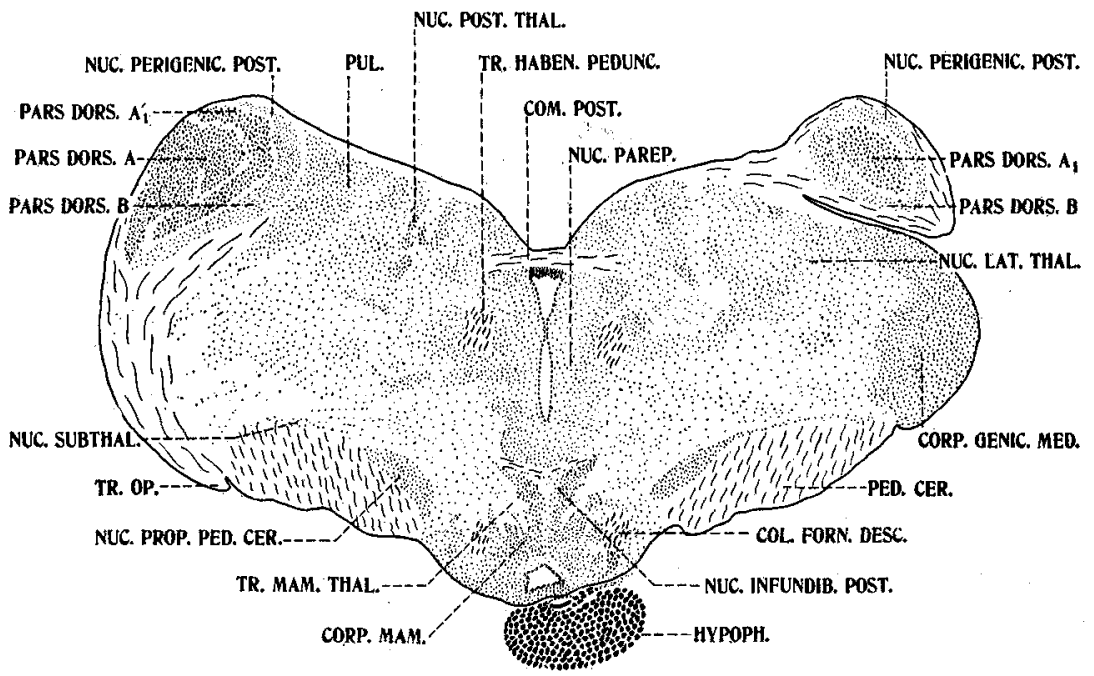

Fig. 14 Transverse section of the thalamus of the cat through the region of the posterior commissure. The section cuts the left lateral genieulate nueleus more anteriorly than the right. $\times 4$. Toluidin-blue series, no. 1: 141:1. col.forn.desc., columna fornicis descendens; com.post., commissura posterior; corp.genic.med., corpus geniculatum mediale; corp.mam., corpus mamillare; hypoph., hypophysis; nuc.infundib.post., nucleus infundibularis posterior; nuc.lat.thal., nucleus lateralis thalami; nuc.parep., nucleus parependymalis; nuc.perigenic.post., nueleus perigeniculatus posterior; nuc.post.thal., nucleus posterioris thalami; nuc.prop.ped.cer., nucleus proprius pedunculus cerebri; nuc.subthal., nueleus subthalamicus; pars dors. $A, A_{1}, A_{1}{ }^{\prime}, B$, pars dorsalis $\mathrm{A}, \mathrm{A}_{1}$, $\mathrm{A}_{2}^{\prime}$, B; ped.cer., pedunculus cerebri; pul., pulvinar; tr.haben.pedunc., tractus habenulopeduneularis; tr.mam.thal., tractus mamillothalamicus; tr.op., tractus optieus.

they form a pale shell covering the dorsal and lateral surfaces (figs. 3 and 15). A few of this type of cell are scattered over the dorsal surface of the pars dorsalis A for quite a distance caudally, but whether or not these represent a true continuation of the nucleus perigeniculatus anterior is not certain. 
The nucleus also appears to be continuous ventrolaterally with the pars ventralis B (figs. 4 to 7 ), and although its cells are different in character from those of the pars ventralis $B$, the two nuclei are no doubt closely associated as Woollard ('26) and Minkowski ('13) have suggested.

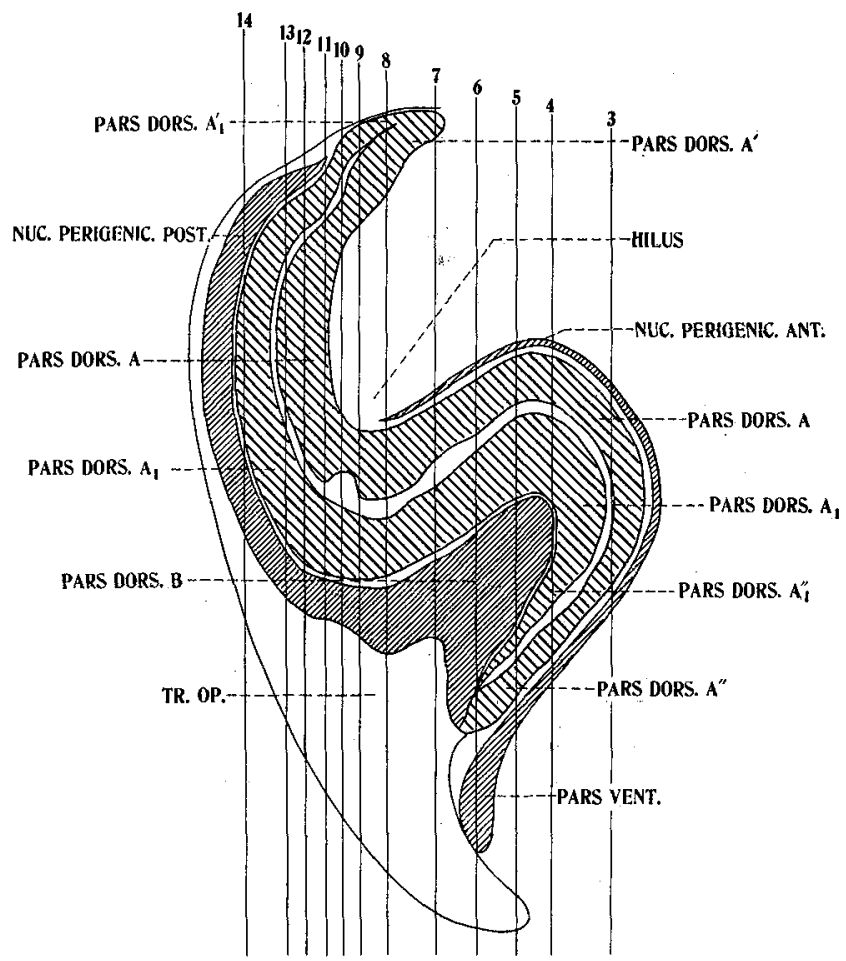

Fig. 15 Schematic representation of a longitudinal section through the lateral geniculate nucleus of the cat, reconstructed from the series of transverse sections. The plane of this diagram is not strictly dorsoventral, but is inclined toward the midline at an angle of $30^{\circ}$ from the vertical, as is shown by the arrows on each of figures 3 to 14 . Since the nueleus inclines in this direction, a longitudinal section so taken gives a more accurate picture of the internal con. figuration of the nucleus than a section in the vertical plane. The vertical lines traversing the diagram locate the transverse sections drawn in figures 3 to 14 . nuc.perigenic.ant., nucleus perigeniculatus anterior; nuc.perigenic.post., nucleus perigeniculatus posterior; pars dors. $A, A^{\prime}, A^{\prime \prime}, A_{1}, B$, pars dorsalis $\mathrm{A}, \mathrm{A}^{\prime}, \mathrm{A}^{\prime \prime}$, $A_{1}, B$; pars vent., pars ventralis ; tr.op., tractus opticus. 

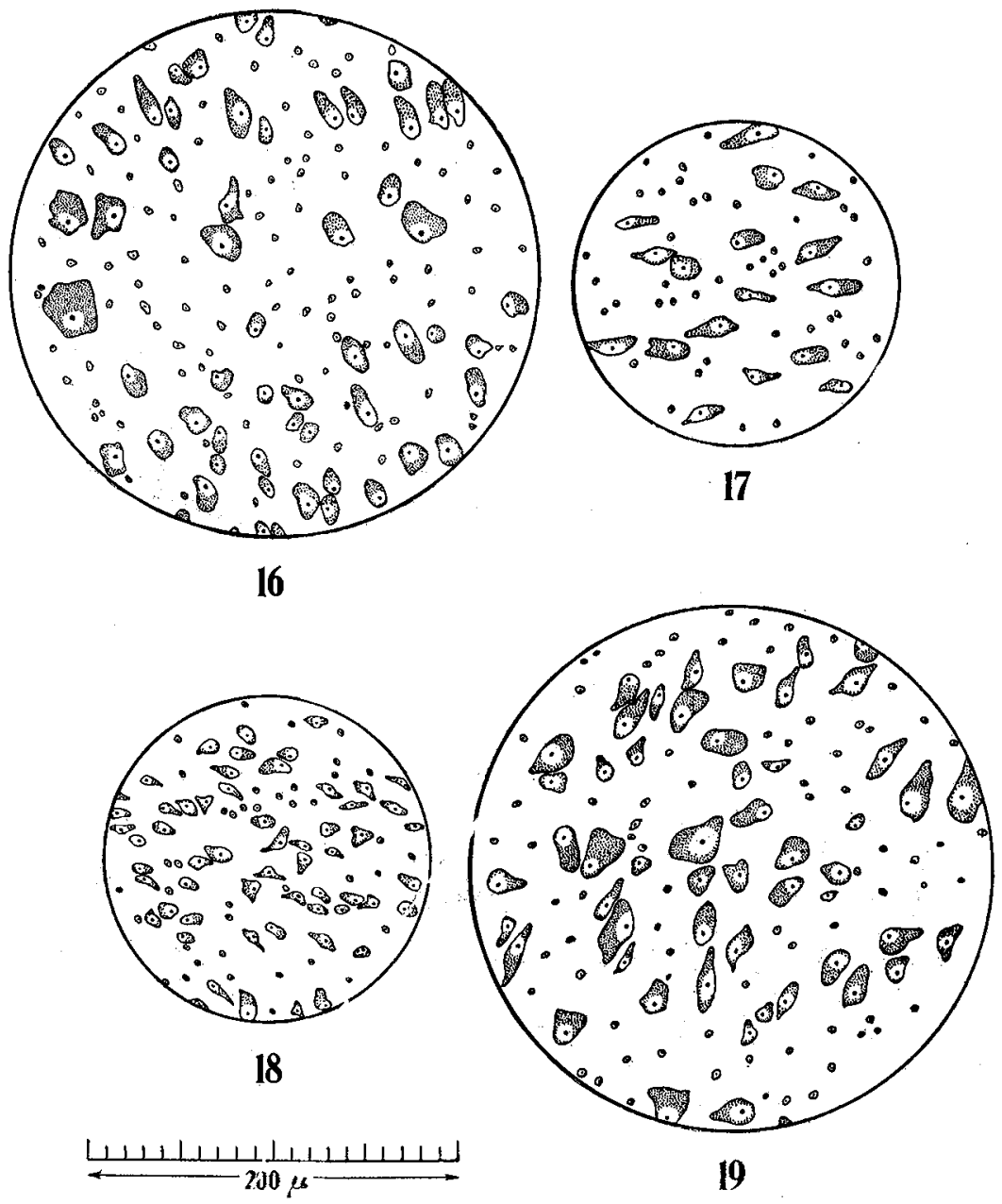

Fig. 16 Camera lueida drawing of the eells in the fiber lamina between pars dorsalis $A$ and $A_{1}$. The site of the drawing is indicated in figure 8.

Fig. 17 Camerd-lucida drawing of the cells in pars dorsalis $B$. The site of the drawing is irdicated in figure 7.

Fig. 18 Camera-lucida drawing of the cells in pars ventralis. The site of the drawing is indicated in figure 7 .

Fig. 19 Canera-lueida drawing of a portion of one of the clusters of cells designated as the nucleus interlaminaris medialis. The site of the drawing is indicated in figure 10. 
Pars ventralis. As noted above, this nucleus appears to develop as an associate of the nucleus perigeniculatus anterior and appears as an enlargement of the ventrolateral portion of that nucleus (figs. 5 and 15 ). The cells are small and stain relatively faintly. On the average they measure 5 to $10 \mu$ in length and are somewhat longer than wide (fig. 20, D).
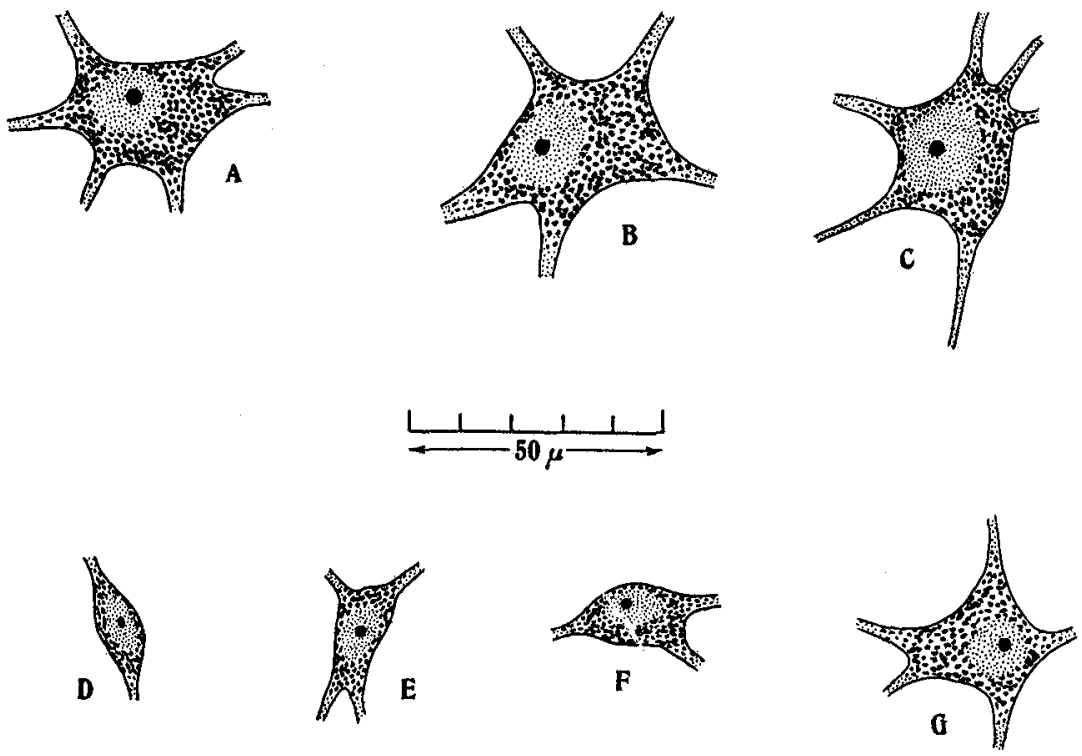

Fig. 20 Camera-lucida drawings made with an oil-immersion objeetive of typical cells from the lateral geniculate body of the adult cat. $A$, cell from pars dorsalis A. B, cell from nucleus interlaminaris centralis, C, cell from nucleus interlaminaris medialis. $\mathrm{D}$, cell from pars ventralis. $\mathrm{E}$, cell from pars dorsalis B. F and $G$, cells from pars dorsalis $A$.

Scattered throughout this nucleus are a few cells which appear to be of the same variety as those which constitute pars dorsalis B (fig. 20, E).

From its point of origin, about $0.8 \mathrm{~mm}$. caudad to the oral pole of the pars dorsalis $A$, the pars ventralis develops into a triangular nucleus, the apex of which is directed dorsally (figs. 5 and 6 ). It is intercalated between the lateral branch of the optic tract and the ventrolateral tip of the pars dorsalis 
A (fig. 5). Ventrally, the nucleus trails out into a line of scattered cells which curve ventromedially toward the lateral thalamic nuclei in a position previously occupied by the ventral part of the nucleus semilunaris thalami.

The pars ventralis presents this appearance for a number of sections caudally until the internal branch of the optic tract splits it into two portions, a dorsal portion which is caught between the branches of the tract medially and ventrally and the pars dorsalis A, dorsally and a ventral portion, a small group of cells immediately ventral to the medial branch of the tract. This situation is shown in figure 7 .

As more and more optic fibers swing into the main mass of the lateral geniculate body, the pars ventralis is rapidly obliterated and finally disappears as a few cells at the ventrolateral tip of the pars dorsalis A (fig. 8).

It may be noted here that the pars ventralis, designated by Tello as the 'núcleo accesorio' and by Minkowski as the 'ventraler kleinzelliger Kern,' is regarded by these authors as the homologue of the ventral nucleus of lower forms. Winkler and Potter ('14) refer to a pars ventralis a and a pars ventralis $b$, but which is ' $a$ ' and which ' $b$ ' is not clear to us from the plates (pls. 12 and 12a). On the basis of plate 12, their pars ventralis $b$ appears to be the pars ventralis of this paper. We have not been able in the present preparations to identify with certainty their pars ventralis a.

\section{DISCUSSION}

It was pointed out in the introduction to this paper that the tendency in the past has been to embark on experimental studies of the function of the lateral geniculate body and its relationship to the retina and cortex without sufficient background in the normal anatomy of the nucleus. And now, if the perusal of this paper has given the reader a somewhat more complete idea of the complexity of the lateral geniculate body in the cat, it may be in point to give a brief review of findings of Minkowski. ('13) and Overbosch ('27) in the light of a more detailed knowledge of the normal structure of the lateral geniculate than has heretofore been available. 
In studying the projection of the retina on the lateral geniculate body, Minkowski sectioned the optic nerve and observed secondary degenerations in the cells of termination, i.e., chromatolysis engendered by disuse. By means of Nissl and carmine preparations, he noted that, in general, after enucleation of the bulb, alternate cell laminae atrophied. Since one of his photographs corresponds quite closely to figure 6 of this paper, we may use this figure to illustrate his findings. Thus, after enucleation of the contralateral eye, pars dorsalis A (äussere periphere Schicht) degenerated, pars dorsalis $A_{1}$ (zentrale Schicht) remained normal, pars dorsalis B (innere periphere Schicht) showed atrophic changes, and pars ventralis (ventraler kleinzelliger Kern) degenerated slightly. In the homolateral geniculate body practically the converse was the case, those parts which atrophied in the contralateral geniculate remaining normal in the nucleus of the same side as the lesion.

In longitudinal relations he finds that the crossed fibers command the entire cross-section of the oral pole, while in the main mass of the nucleus they have as a terminal field the peripheral part of the section. On the other hand, the uncrossed fibers are absent in the oral pole and in the remaining sections terminate in the central region. The pars ventralis (ventraler kleinzelliger Kern) appears to receive only crossed fibers, and but a few of these.

But while Minkowski finds that the crossed and uncrossed cell complexes are sharply separated by the medullary laminae, the work of Overbosch seems to show a projection of the retina on the lateral geniculate body which is independent of histological structure or cellular lamination. Unfortunately, at the time of writing this paper, Overbosch's original work is unavailable, and we are forced to be content with the review which Brouwer and Zeeman ('26) have given and the diagram from Overbosch which they have reproduced.

According to these authors, Overbosch made small lesions in various regions of the cat's retina and studied degenerated fibers by means of the Marchi method. He finds that the 
retina is represented in the contralateral geniculate body as an inverted image, i.e., the lower quadrants are localized dorsally; the upper quadrants, ventrally, and the temporal and nasal quadrants, laterally and medially, respectively. The uncrossed fibers, i.e., those from the temporal quadrants of the homolateral retina, terminate in the medial portion of the lateral geniculate. As regards Overbosch's findings for the ventral and perigeniculate nuclei, Brouwer and Zeeman are silent.

The difference between these results and those of Minkowski, Brouwer and Zeeman attribute, and no doubt justly, to the difference in methods used. As was mentioned, Minkowski's results are based on the atrophy of cells deprived of stimuli from the retina, while the results of Overbosch depend on the site of termination of degenerated optic fibers. So far as the projection of the retina on the lateral geniculate is concerned, Overbosch's method would seem to be the more reliable, since that used by Minkowski may well be charged with providing an incomplete picture. Although it may pick out cells which receive their stimuli solely from the optic tract, it may legitimately be supposed that there are also cells in the lateral geniculate which receive impulses from other sources as well as from the retina, and hence would not necessarily atrophy when deprived of stimuli from the eye. Therefore, it appears to the writer that one might justifiably argue that the cell laminae which did not atrophy in Minkowski's case after enucleation of the bulb might receive fibers from the optic tract and still not degenerate, because of the presence of stimuli from other sources, and that the atrophied laminae were supplied solely, or at least to a very great extent, by fibers from the retina.

Apparently, then, if this interpretation of Minkowski's results is legitimate, the differentiation of the lateral geniculate body of the cat into relatively complex lamination is associated with the increase of non-optic stimuli to that nucleus, and that differentiation in this case may mark the development of the lateral geniculate as a correlating mechan- 
ism rather than merely as a relay station to the cortex. And such would seem reasonable on analogy with the phylogenetic development of the cerebral cortex and dorsal thalamus. However, in the light of the limitations of our present knowledge, this verges on speculation and as such is outside the scope of the present paper. It is the intention of the writer to continue this investigation so as to embrace a study of the fiber relations of the lateral geniculate body of the cat, based on silver and iron haematoxylin preparations. With this study completed, and taken in connection with the present communications, a background is at hand which, it seems to the writer, would give us a better foundation for experimental investigations of the functional pattern of the nucleus.

\section{SUMMARY}

In concluding, we may state that, on the basis of a study of a toluidin-blue series of the corpus geniculatum laterale of the cat, this nucleus is found to be composed of five histologically distinct entities:

1. A pars dorsalis $A$ and $A_{1}$, making up the main body of the nucleus, which in longitudinal relations is an' $S$ '-shaped structure traversed from top to bottom by a medullary lamina which communicates by a medullary canal with an anterior hilus; this portion is characterized by a more or less homogeneous distribution of large, medium, and small cells.

2. A pars dorsalis $B$, located ventrally to the pars dorsalis $A_{1}$ and in close association with it, is composed of small spindle-shaped cells.

3. A pars ventralis is situated ventrolaterally of the pars dorsalis and separated from it by a thin medullary lamina, composed of small pale cells, among which are scattered a few of the cells of the type found in pars dorsalis $B$.

4. A nucleus perigeniculatus anterior, forming a thin shell over the caudal surface of the pars dorsalis, is composed of small, very poorly staining cells. It appears continuous ventrally with the pars ventralis $B$. 
5. A nucleus perigeniculatus posterior, forming a cap over the caudal pole of the pars dorsalis, is composed of small pale cells. It is apparently closely associated with the pars dorsalis $\mathrm{B}$, with which it appears to be continuous.

In addition to these facts is noted the presence of very large and deeply staining cells scattered throughout the medullary laminae traversing the main mass of the nucleus, which cells have been designated collectively as the nucleus interlaminaris centralis. The term nucleus interlaminaris medialis has been applied to clusters of cellular elements similar to those found in the pars dorsalis, which are found in the thin fiber laminae medial to the main mass of the nucleus.

\section{BIBLIOGRAPHY}

Artëns Kappers, C. U. 1921 Vergleichende Anatomie des Nervensystems, Bd. 2.

Brouw ER, B. 1923 Experimentellanatomische Untersuchungen über der Projection der Retina auf die primären Opticuszentren. Schweiz. Areh. f. Neurol. u. Psych., Bd. 13, S. 118-137.

Brouwer, B., ANd Zeeman, W. P. C. 1926 Projection of the retina in the optic neuron in monkeys. Brain, vol. 49, pp. 1-36.

Henschen, S. E. 1926 Zur Anatomie der Sehbahn und des Sehzentrums. Areh. f. Ophthal. (v. Graefe). Bd. 117, S. 403.

HUber, G. CARL 1927 New method of fixation and staining of the central nervous system for the purpose of study of eytoarchitecture. Contributions to medical science dedicated to Aldred Scott Warthin. Ann Arbor.

Minkowski, M. 1913 Experimentelle Untersuchungen über die Beziehungen der Grosshirn und der Netzhaut zu den primären Opticuszentren, etc. Arbeiten a. d. Hirnanat. Inst. zu Zurich., Bd. 7, S. 259-362.

1919 Ueber den Verlauf, die Endigung und die zentrale Repräsentation von gekreuzten und ungekreutzen Sehnervenfasern bei einigen Säugetieren und beim Menschen. Schweizer Arch. f. Neurol. $u$. Psych., Bd. 7, S. 201.

v. Monakow, C. 1914 Localization im Grosshirn. Wieshaden.

PolJAK, S. An experimental study of the association callosal, and projection fibers of the cerebral cortex of the cat. Jour. Comp. Neur., vol. 44, no. 2, pp. 197-258.

Putman, T. J. 1926 Studies on the central visual system. II. A comparative study of the geniculo-striate visual system of mammals. Arch. of Neurol. and Psych., vol. 16, pp. 285-300.

RAMóN Y CAJAL, S. 1911 Histologie du système nerveux, T. 2. Paris. 
Tello, F. 1904 Disposición macroseópica y estruetura del cuerpo genienlado externo. Trabajos del Laboratorio de investigaciones Biológicas de la Universidad de Madrid. Tomo 3, pp. 39-62.

WINketer, C., AND PoTTER, A. 1914 An anatomical guide to experimental researches on the cat's brain. Amsterdam.

Woollard, H. H. 1926 Notes on the retina and lateral geniculate body in tupaia, tarsius, nyeticebus and hapale. Brain, vol. 49, pp. 77-105.

PLATE 1

EXPLANATION OF FIGURE

2 Photographs of the cardboard model of the pars dorsalis of the left lateral geniculate body of the cat. The pars ventralis $\mathbf{B}$ and the perigeniculate nuelei are not included. The model is so oriented in the photograph that the left side of the page is cephalad and the upper edge dorsad. (A) represents the articulated model and (B) the same with the separable sections pulled slightly apart, to show the internal construction. (Photographed with the aid of Dr. Paul S. MeKibben.) 

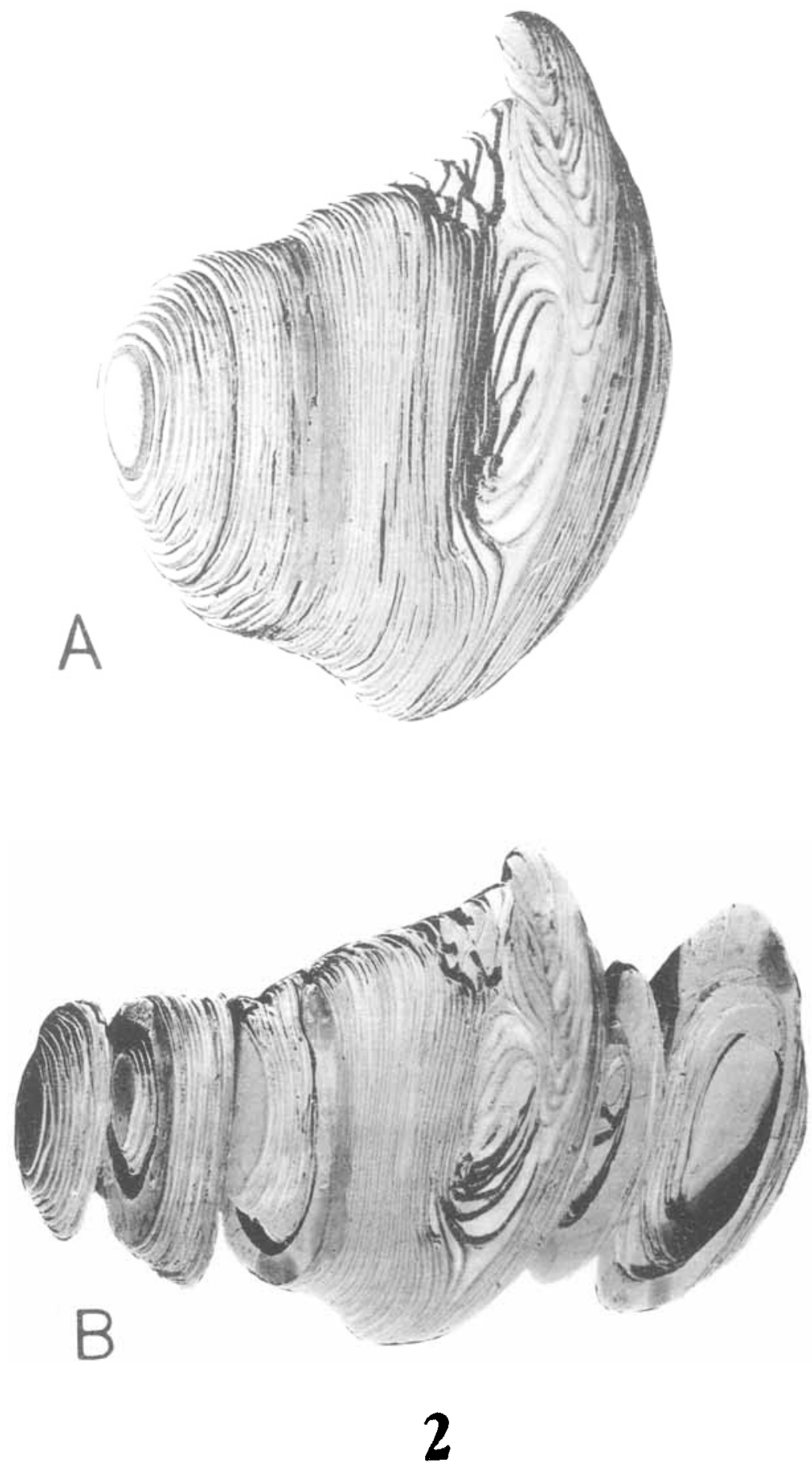